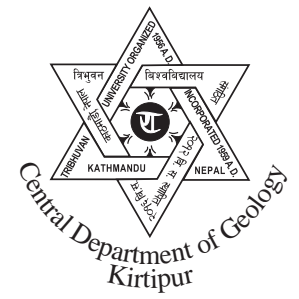

\title{
Stability and stress analyses of headrace tunnel, Upper Seti Storage Hydroelectric Project, Western Nepal
}

\author{
*Niraj Kumar Regmi ${ }^{1}$, Prakash Chandra Adhikary1, Jayandra Man Tamrakar² \\ and Rabindra Prasad Dhakal ${ }^{3}$ \\ ${ }^{1}$ Central Department of Geology, Tribhuvan University, Kathmandu, Nepal \\ ${ }^{2}$ Engineering Services, Nepal Electricity Authority, Kathmandu, Nepal \\ ${ }^{3}$ Sunkoshi Hydropower Company Limited, Indrawati IV Hydroelectric Project, Melamchi, Nepal
}

\begin{abstract}
The Upper Seti (Damauli) Storage Hydroelectric Project has a capacity of $128 \mathrm{MW}$, the storage type scheme, and includes $1000 \mathrm{~m}$ long horse shoe headrace tunnel, $140 \mathrm{~m}$ high concrete gravity dam, two diversion tunnels of lengths $712 \mathrm{~m}$ and $881 \mathrm{~m}$ and an underground powerhouse. The study was carried out to identify stability and stress conditions for the headrace tunnel to suggest the required tunnel support. The project area extensively covers dolomite and minorly covers slate. The rock mass classification showed fair to good quality of dolomite and poor to fair quality of slate. The surface wedges would form in intake portal and powerhouse site. In the headrace tunnel, structural wedges would be formed due to underground excavation and would be stabilized with the help of shotcrete and rock bolting.
\end{abstract}

\section{INTRODUCTION}

In spite of potential resources of hydropower, Nepal has faced power crisis for several years because most of the hydropower developed so far depends on the river run-off schemes except Kulekhani-I (60 MW) (Regmi 2003). To meet the power crises, storage scheme will be quite essential for the country. Untill now the total installed capacity of hydropower in Nepal is about 614 MW as reported by NEA (2006). About $70 \mathrm{MW}$ will be fulfilled by Middle Marsyangdi Hydroelectric Project that is in the last phase of construction.

The Upper Seti (Damauli) Storage Hydroelectric Project with capacity of $128 \mathrm{MW}$ will have the storage type scheme (NEA 2001; NEA 2006). The main features of the project includes $1000 \mathrm{~m}$ long horse shoe headrace tunnel, $140 \mathrm{~m}$ high concrete gravity

\footnotetext{
*Corresponding author:

E-mail address: nirajregmi@gmail.com
}

dam, two diversion tunnels of lengths $712 \mathrm{~m}$ and 881 $\mathrm{m}$ and an underground powerhouse.

The aim of the study is to identify design parameters for the headrace tunnel to suggest the required tunnel support. In the project the rock mass was classified according to rock mass rating (RMR) as suggested by Bieniawski (1989). The required support was calculated based on the rock mass class. Stress analysis for headrace tunnel was carried out using empirical ralations. Geotechnical design of the headrace tunnel and portal slope was carried out using the softwares, UNWEDGE and SWEDGE (Rocsciences Inc 2003), respectively.

The project area lies in the lower reach of the Seti River south of Damauli, Western Nepal Lesser Himalaya (Fig. 1). The Damsite is located in a narrow gorge in the river about $2 \mathrm{~km}$ upstream from the confluence of the Seti River and the Madi River. The powerhouse site is located about $2 \mathrm{~km}$ downstream from the confluence. Based on Jnawali and Tuladhar 


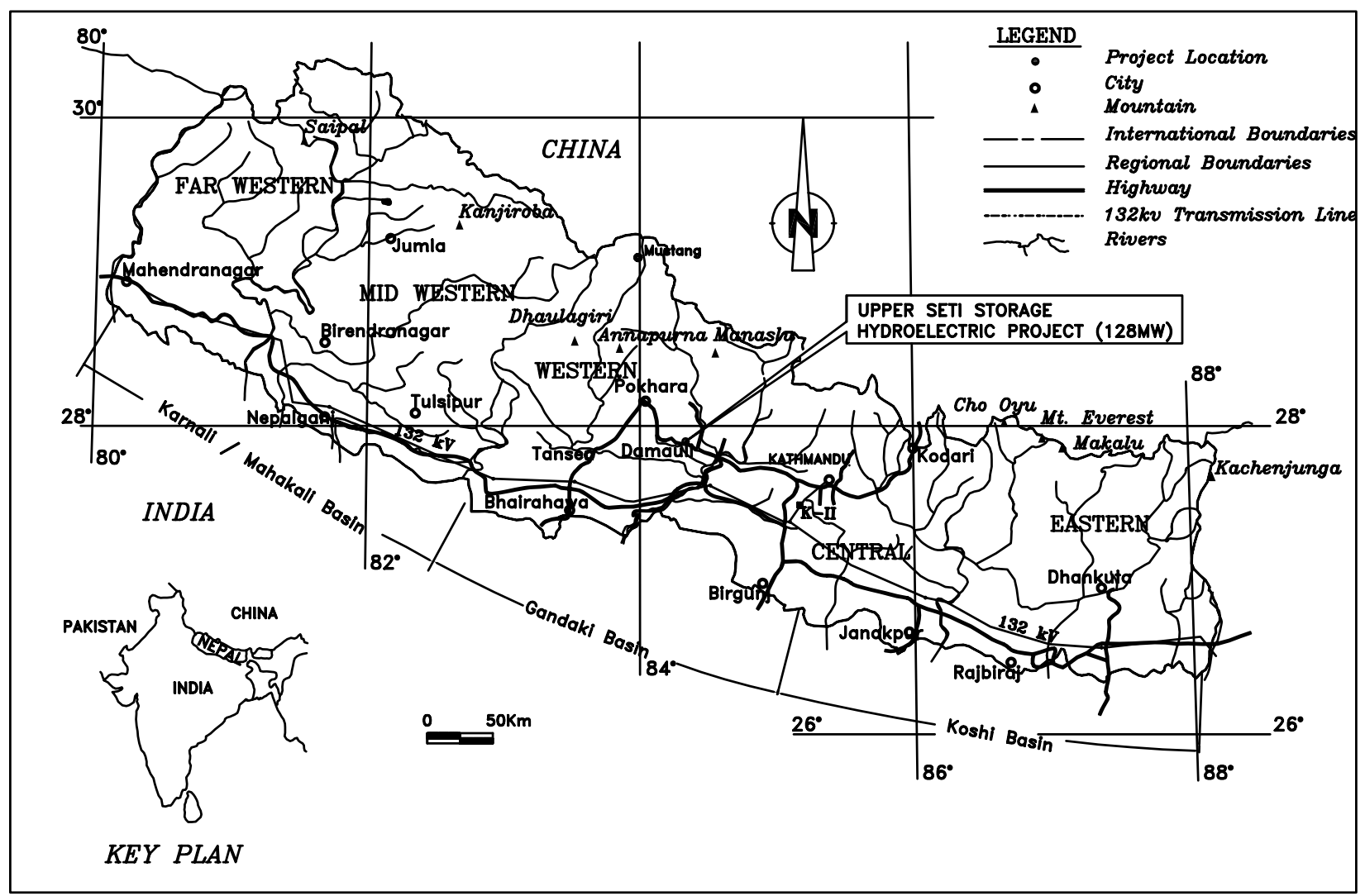

Fig. 1 Location map of the project

(1996) the Lesser Himalayan rocks in the project area are represented by the Dhading Dolomite, the Benighat Slate and the Nourpul Formation (Fig. 2). The Dhading Dolomite consists of bluish grey to light grey and crystalline dolomites. The Benighat slate is mainly black slate. The Nourpul Formation comprises dark green to greenish grey phyllite and light grey quartzite.

The major hydraulic structures of the project are intake portal, spillway, diversion tunnel concrete gravity dam, headrace tunnel, undergroupd powerhouse and tailrace tunnel which are located mainly in the Dhading Dolomite and the Benighat Slate.

\section{GEOLOGY OF DAM AND TUNNEL SITES}

The dam site is situated in a $25 \mathrm{~m}$ wide gorge of the Seti River about $2 \mathrm{~km}$ upstream from the Madi River confluence. The river has steep slopes on banks near the dam axis (Fig. 3). The rock outcrops on both banks extend for more than $200 \mathrm{~m}$ upstream and downstream from the dam axis. The bank slopes were bore holed (Fig. 4) by NEA (2001). The depth of bedrock in the river channel was estimated to be 15 $\mathrm{m}$ below the riverbed. Some cavities were observed in the dam site, however no major caverns were found.

Dolomite is the predominant rock of the dam site and is slightly to moderately weathered, highly jointed, blocky to seamy with fractures. The dolomite is medium strong to strong with uniaxial compressive strength (UCS), derived empirically from the pointload index for lump samples, varying from 80 to 181 $\mathrm{MPa}$. The rock quality designation (RQD), from surface estimation and volumetric analysis of joints of the dolomite, ranges from $50 \%$ to $75 \%$. The strike of the beds is nearly perpendicular to the river flow. Three to five sets of prominent joints exist in the dolomite and are tight, occasionally 50 to $300 \mathrm{~mm}$ open, rough and irregular, moderately spaced with moderate persistency. RMR ranges from fair to good 


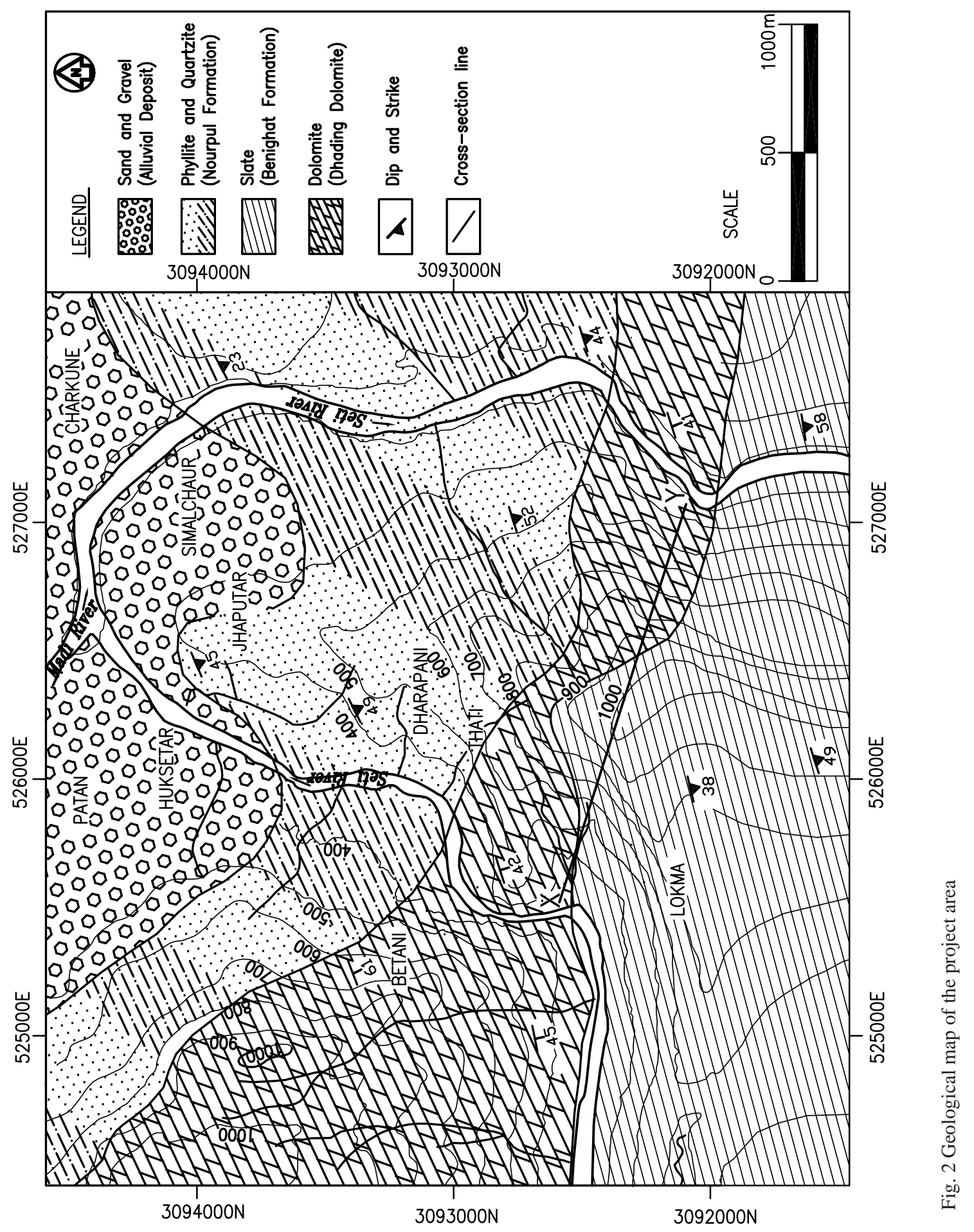




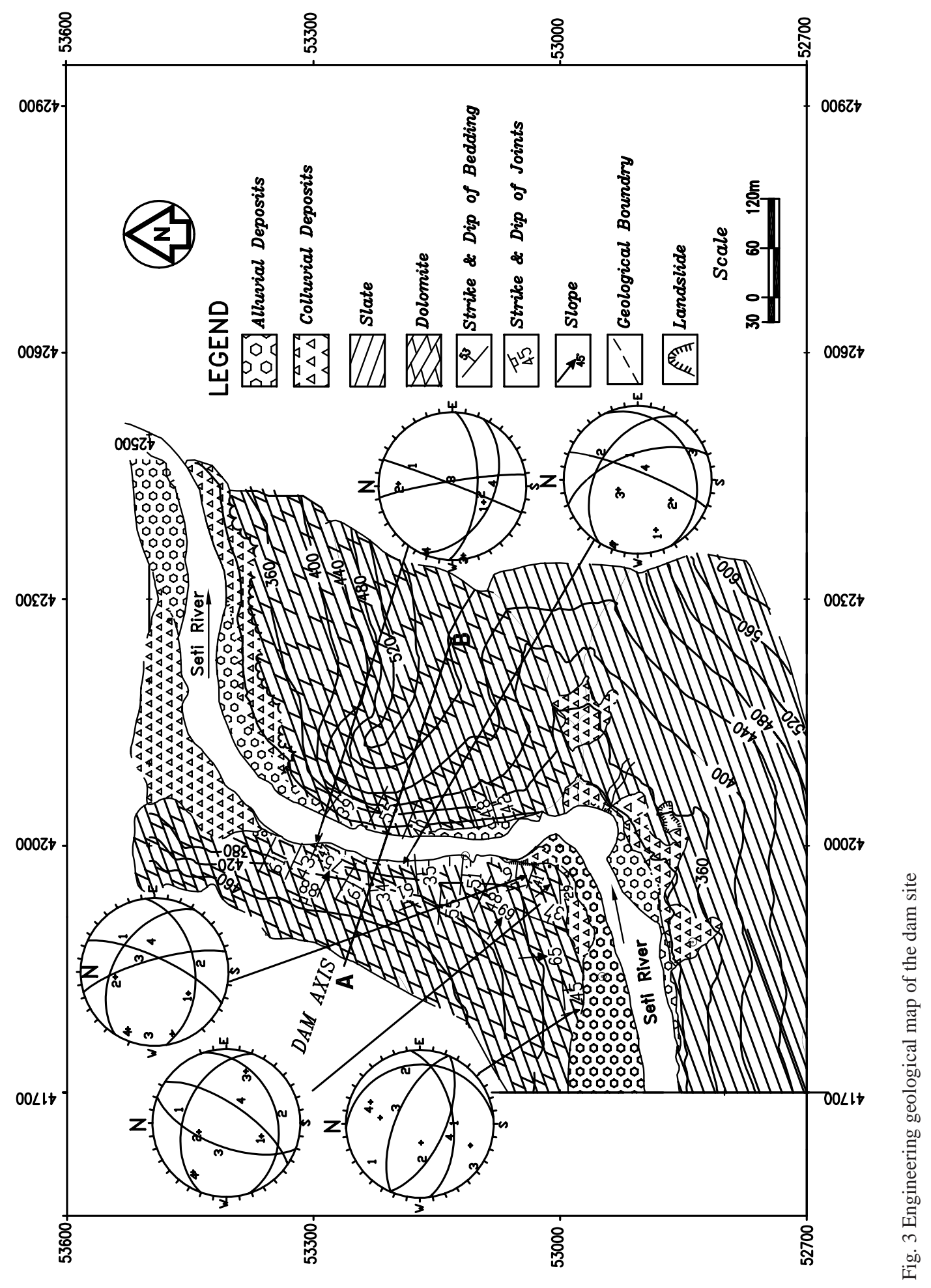


(Bieniawski 1989).

The headrace tunnel is about $1000 \mathrm{~m}$ long and is oriented $\mathrm{N} 70^{\circ} \mathrm{W}$. Tunnel alignment is covered with colluvium and in few places rock is exposed. The headrace tunnel passes through dolomite and slate (Fig. 5). The dolomite is slightly to moderately weathered, highly jointed, blocky to locally fractured. RQD of dolomite is $50-75 \%$ while that of slate is 25-50\%. UCS of dolomite and slate are 91-189 and 13-93 MPa, respectively. RMR for dolomite and slate are 41-80 (fair to good) and 21-60 (poor to fair).

\section{STABILITY AND STRESS ANALYSES}

The data required for the geotechnical design were acquired from geological mapping, point-load test and empirical equations. Deformation modulus of rock $(\mathrm{Em})$, ratio of horizontal to vertical stress $(\mathrm{k})$, vertical stress ( $\mathrm{v}$ ) and maximum tangential stress $\left({ }_{\max }\right)$ of the tunnel opening were calculated using empirical equations. The following assumptions were made prior to calculation of design parameters:

1. The insitu stress and elastic parameter of rock are difficult to acquire at this level of study so the major principal stress $\left({ }_{1}\right)$ was assumed to be equal to vertical stress due to overburden. The minor principal stress ( 3 ) was assumed to be 0.5 times the vertical stress. The intermediate principal stress ( 2 ) was assumed to be sum of 3 and tectonic stress.

2. It was assumed that the ${ }_{1}$ is oriented vertically and the 3 was oriented horizontally, the 3 was oriented in the axes of the underground opening.

3. Elastic and plastic parameters were taken from empirical relation proposed by Hoek et al (1995).

\section{Cutslopes in dam site and intake portal}

The intake portal of the headrace tunnel is located on the right bank of the Seti River. The natural slope of the intake portal area is 40 degrees. The portal area has steep slope, rocky cliff of dolomite that dips towards the slope face. Joint system of the dolomite outcrops was analysed using the program DIPS. The friction angle was assumed 30 degrees. Out of three prominent joint sets, the set 1 and set 3 intersect forming a wedge that closely falls within a wedge- sliding zone.

The surface wedge stability was carried out using a software SWEDGE. The face slope can be excavated at $50^{\circ}$ to $60^{\circ}$ or more at slope height 30 to $40 \mathrm{~m}$, when the rock slope stability analysis was made assuming unit weight of the rock equals 2.7 tons $/ \mathrm{m}^{3}$, nil water pressure, and non-cohesive state. However, at $50^{\circ}$ of face slope and slope height of $40 \mathrm{~m}$, a wedge may produce. The wedge thus formed will have a weight of 11500 tons having factor of safety 0.93 and line of intersection $156^{\circ} / 33^{\circ}$. To stabilize the wedge, rock bolts having capacity of 1000 tons and length 10-14 may be applied and this would increase the factor of safety to 1.74 .

\section{Stability analysis in headrace tunnel}

The underground stability analysis of the headrace tunnel alignment was carried out by using the software UNWEDGE. Unit weight of dolomite was assumed to be 2.7 tons $/ \mathrm{m}^{3}$ and friction angle of 30 degrees. As in dam site and tunnel portal, three sets of prominent joints were found in dolomite. These joint sets and tunnel alignment produce structural wedges at roof, side walls and and floor of the tunnel (Figs. 6 and 7). To stabilise the so formed wedge, bolting and shotcrete were used.

For the wedge 1 produced at roof, shotcrete of $100 \mathrm{~mm}$ thick with shear strength 25 tons $/ \mathrm{m}^{2}$ and bolting should be used. The bolts having $6 \mathrm{~m}$ length and 1000 tons bearing capacity should be applied. Bolts will have to be installed at normal to the boundary in $2 \mathrm{~m} \mathrm{x} 2 \mathrm{~m}$ spacing to achieve factor of safety of 1.62 (Fig. 8).

\section{Stress analysis of headrace tunnel}

Stress condition of the headrace tunnel was analysed using empirical relations and analysis using elastic and plastic behavior.

\section{In situ deformation modulus}

The in situ deformation modulus is difficult and expensive to determine in the field. This value was estimated using the rockmass classification and the following reations:

$\mathrm{Em}=2 \mathrm{RMR}-100$ 


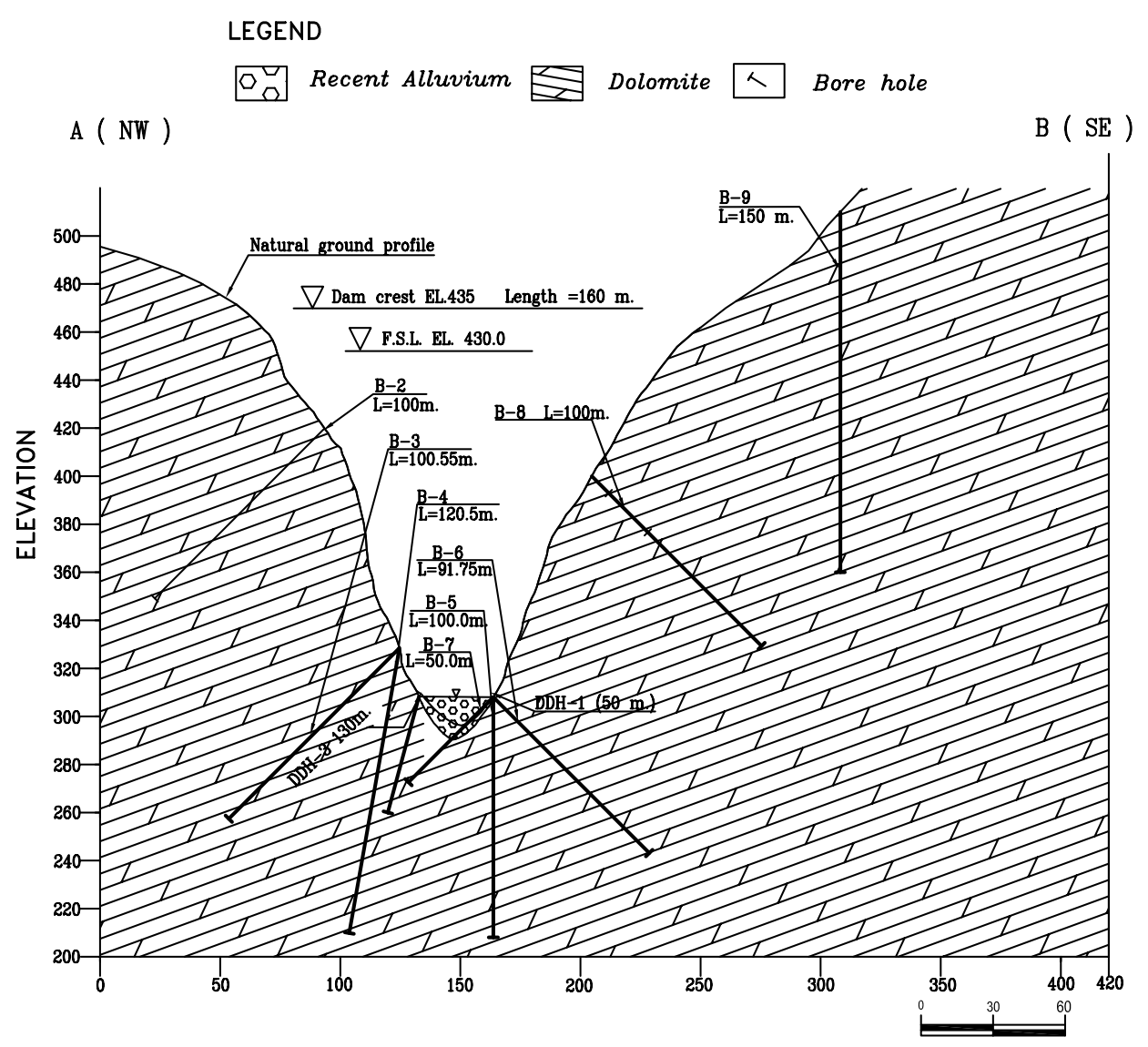

Fig. 4 Geological profile of dam site along A (NW)-B (SE); (see Fig. 3 for the line of the profile)

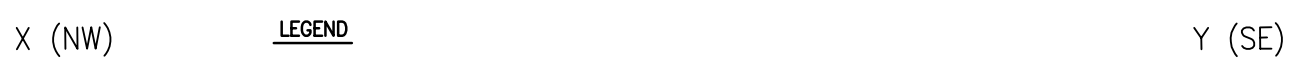

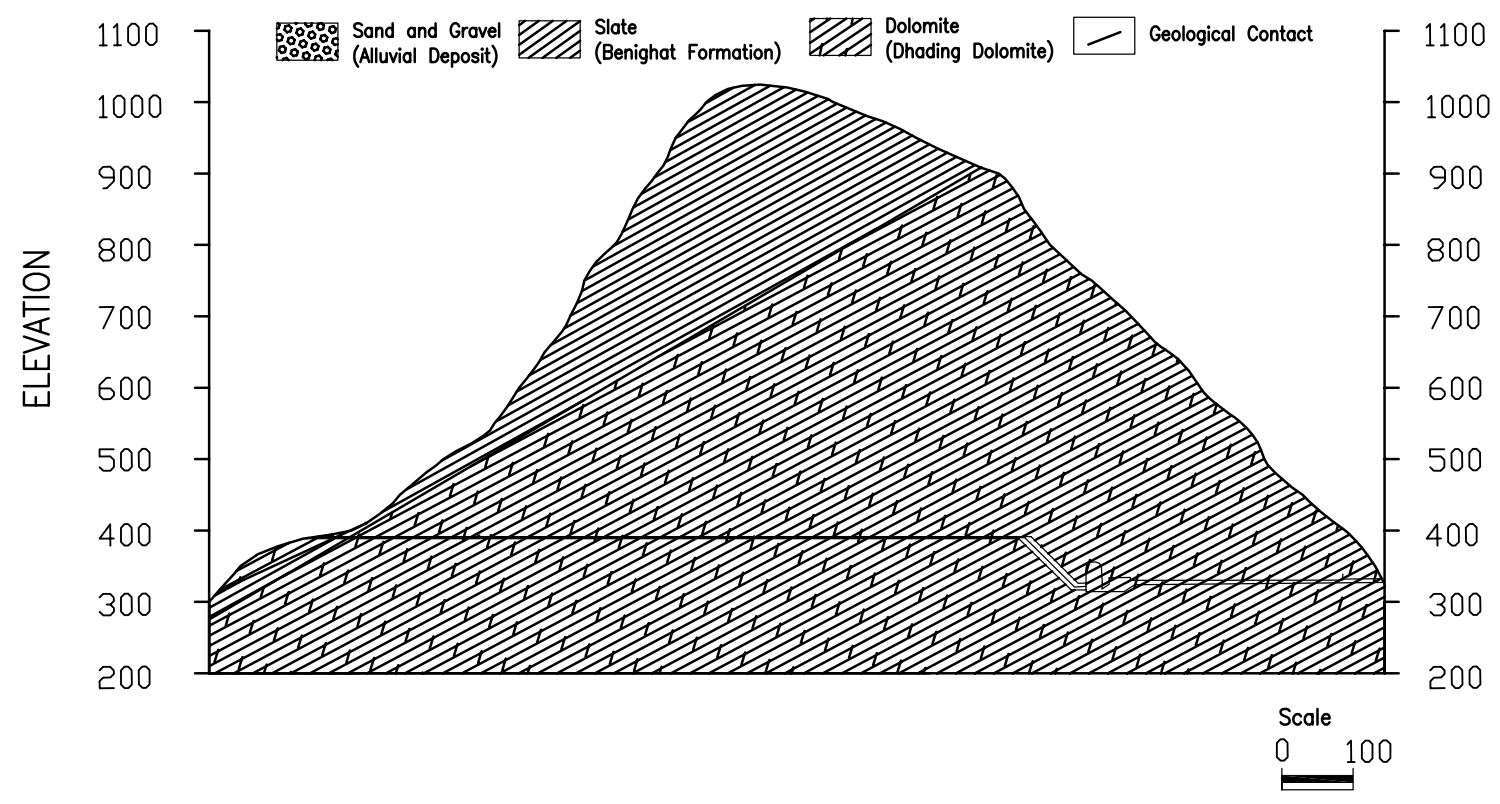

Fig. 5 Geological profile of the headrace tunnel between intake and powerhouse 


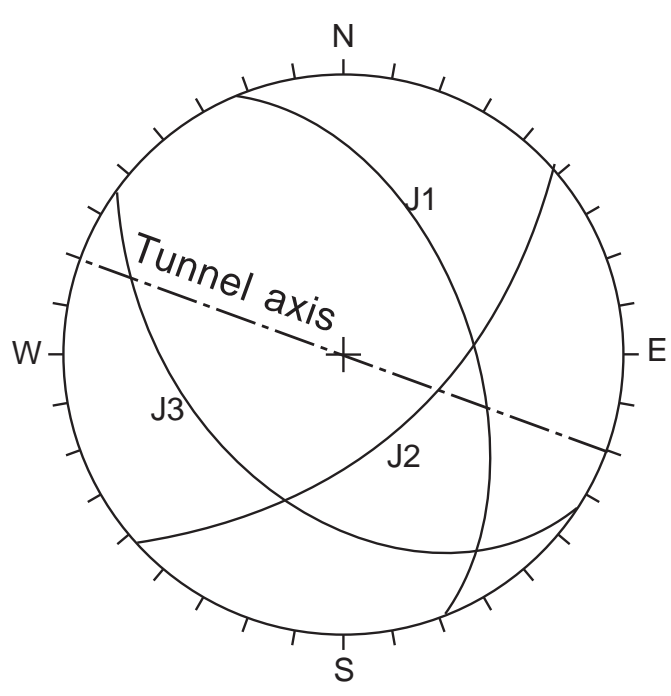

Fig. 6 Stereographic projection of joint sets of dolomite and azimuth of tunnel axis

(Bieniaswki 1978)

$\mathrm{Em}=10^{(\mathrm{RMR}-10) / 40}$

(Serafim and Pereira 1983)

$\mathrm{Em}=25 \log _{10} \mathrm{Q}$

(Grimstad and Barton 1993)

The main rock types of the tunnel are dolomite and slate. The present study focuses on deformation modulus only for dolomite, because the slates are difficult to analyse. Rock mass rating value and $\mathrm{Q}$ value were calculated from rock mass characteristics; joints, strength, etc. RMR of 55 and Q value of 2.7 were used for calculating Em. Although the calculated Em do not largely differ with one another, the value obtained from equation (3) that was $11 \mathrm{GPa}$, was considered in the present analysis.

\section{In situ stress}

Basic governing parameter for the stability of rocks inside the tunnel is orientation of joints, its separation and pressure caused by the overburden or the rock cover. The vertical stress ( v) acting on a tunnel was estimated from the relationship:

$$
\mathrm{v}=\mathrm{z}
$$

where = unit weight of the overlying rock and $\mathrm{z}$ is the depth below the surface in meter. The maximum rock cover in the headrace tunnel is 720 $\mathrm{m}$. Using equation (4) the vertical stress was 19.44 MPa.

The horizontal stress acting on the tunnel at a depth $\mathrm{z}$ below the surface is difficult to estimate than vertical stress. Shorey's equetion (1994) was used to estimate the value of horizontal to vertical stress ratio (k) as:

$$
\mathrm{k}=0.25+7 \mathrm{Em}(0.001+1 / \mathrm{z})
$$

Em is the average deformation modulus of the upper part of the earth's crust measured in horizontal direction. Using the maximum rock cover in the headrace tunnel alignment, $\mathrm{z}$ was $720 \mathrm{~m}$ and Em was $11 \mathrm{GPa}$. Using the equation (5) $\mathrm{k}$ was 0.5 and was considered for the analysis.

\section{Elastic and plastic behavior}

The ratio of maximum tangential boundary stress to the unconfined compressive stress of the rock mass, i. e., Damage Index $\left(D_{i}\right)$ was obtained as:

$$
\mathrm{D}_{\mathrm{i}}=\max _{\mathrm{c}} / \mathrm{c}
$$

where, $\max _{\text {ax }}$ is maximum tangential boundary stress ( v $(3 \mathrm{k}-1)$, c is laboratory tested UCS). Damage Index calculated using equation (6) came to be 0.06 . $D_{i}$ less than 0.4 suggests that the rock mass behaves as an elastic condition and there will be no visible damage. If damage index exceeds 0.4 , the rockmass displays a plastic behavior and stress induced damage occurs. For the headrace tunnel, no visible damage will be recorded.

\section{SUPPORT RECOMMENDATION}

The rockmass in tunnel belongs to poor to good rockmass (Class II and Class IV) according to rock mass classification of Bieniawski (1989). About 83\% 


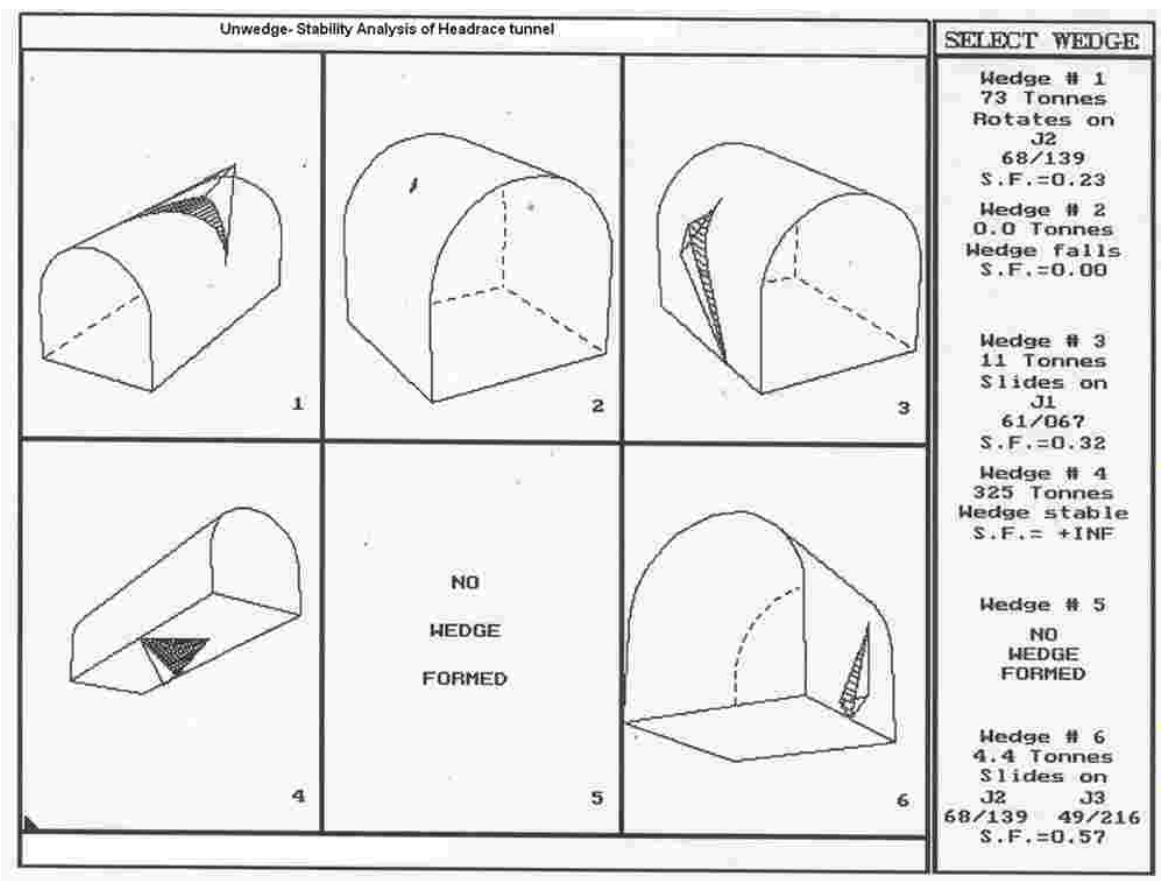

Fig. 7 Stability analysis of the headrace tunnel showing potential wedges

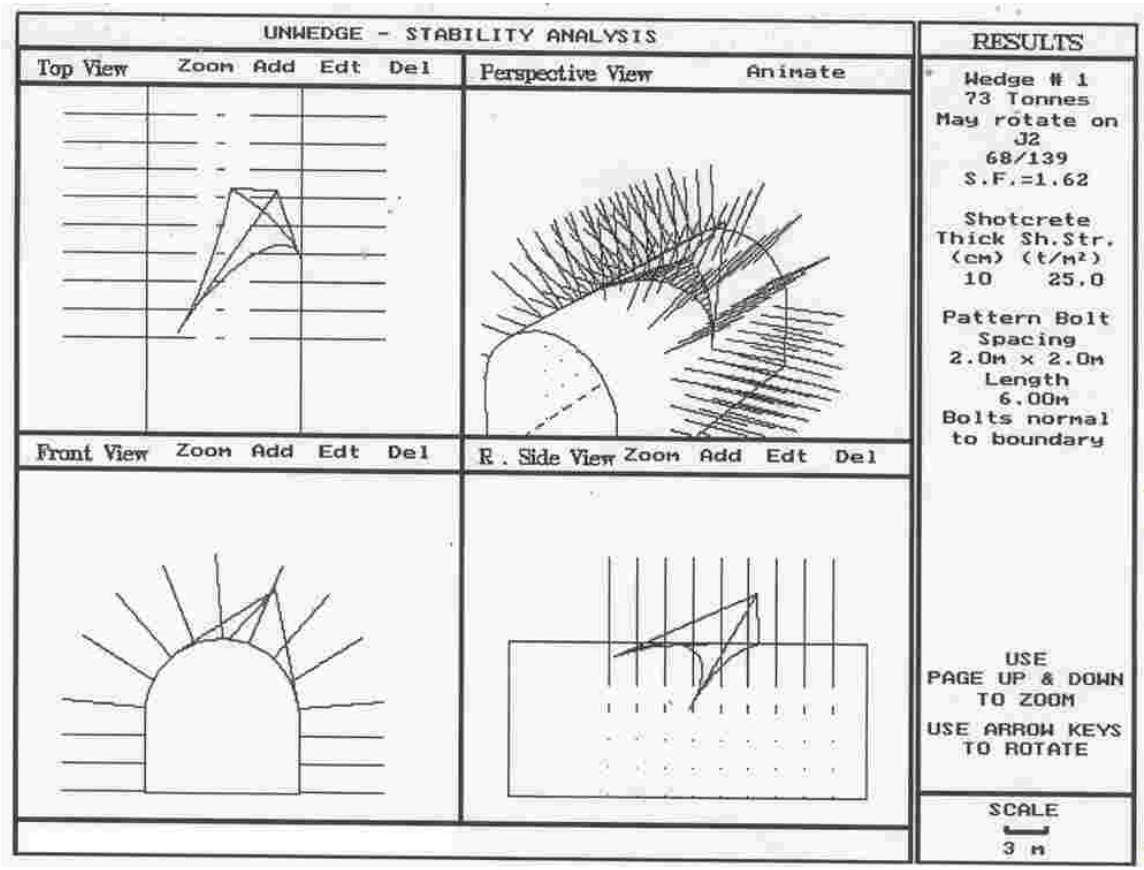

Fig. 8 Stability analysis of the headrace tunnel showing wedges and support system; shotcrete and pattern of bolts 
Table 1: Rock mass classification, excavation method and support recommendation

\begin{tabular}{|c|c|c|c|c|c|c|c|c|}
\hline Structure & $\begin{array}{l}\text { Chainage } \\
\text { (in } \mathrm{m} \text { ) }\end{array}$ & ( $\mathrm{RMR}$ ) & $\begin{array}{l}\text { Rock mass } \\
\text { class }\end{array}$ & $\begin{array}{l}\% \text { tunnel } \\
\text { length }\end{array}$ & $\begin{array}{l}\text { Exc a v a tion } \\
\text { method }\end{array}$ & $\begin{array}{l}\text { Rockbolts }(20 \mathrm{~mm} \\
\text { diameter) fully } \\
\text { grouted }\end{array}$ & $\begin{array}{l}\text { Support } \\
\text { Shotcrete }\end{array}$ & Steel ribs \\
\hline $\begin{array}{l}\text { Headrace } \\
\text { tunnel }\end{array}$ & $0-55$ & $41-80$ & $\begin{array}{l}\text { Fair to good } \\
\text { rock } \\
\text { (Class II and } \\
\text { III) }\end{array}$ & 5 & $\begin{array}{l}\text { Full face } 1.0 \text { to } 1.5 \\
\mathrm{~m} \text { a d v a n c e. } \\
\text { Complete support } 20\end{array}$ & $\begin{array}{l}\text { Locally bolts in } \\
\text { crown, } 3 \mathrm{~m} \text { long } \\
\text { spaced } 2.5 \mathrm{~m} \text { with } \\
\text { occasional mesh }\end{array}$ & $\begin{array}{l}50 \mathrm{~mm} \text { in crown } \\
\text { where required }\end{array}$ & None \\
\hline $\begin{array}{l}\text { Headrace } \\
\text { tunnel }\end{array}$ & $55-176$ & $21-60$ & $\begin{array}{l}\text { Poor to fair } \\
\text { rock } \\
\text { (Class III and } \\
\text { IV) }\end{array}$ & 17 & $\begin{array}{l}\text { Top heading and } \\
\text { bench, } 1.5 \text { to } 3 \mathrm{~m} \\
\text { advancing heading. } \\
\text { Commence support } \\
\text { after each blast. } \\
\text { Complete support } 10\end{array}$ & $\begin{array}{l}\text { Systematic bolts } \\
4 \mathrm{~m} \text { long spaced } \\
1.5 \text { to } 2 \mathrm{~m} \text { in } \\
\text { crown and walls } \\
\text { with mesh in } \\
\text { crown }\end{array}$ & $\begin{array}{l}50-100 \mathrm{~mm} \text { in } \\
\text { crown, } 30 \mathrm{~mm} \\
\text { side walls }\end{array}$ & None \\
\hline $\begin{array}{l}\text { Headrace } \\
\text { tunnel }\end{array}$ & $176-1000$ & $41-80$ & $\begin{array}{l}\text { Fair to good } \\
\text { rock } \\
\text { (Class II) }\end{array}$ & 78 & $\begin{array}{l}\text { Full face } 1.0 \text { to } 1.5 \mathrm{~m} \\
\text { advance. Complete } \\
\text { support } 20 \mathrm{~m} \text { from } \\
\text { face }\end{array}$ & $\begin{array}{l}\text { Locally bolts in } \\
\text { crown, } 3 \mathrm{~m} \text { long } \\
\text { spaced } 2.5 \mathrm{~m} \text { with } \\
\text { occasional mesh }\end{array}$ & $\begin{array}{l}50 \mathrm{~mm} \text { in crown } \\
\text { where required }\end{array}$ & None \\
\hline
\end{tabular}

tunnel length will cross through fair to good rock and $17 \%$ will cross through poor to fair rock. From field observation, empirical approaches and numerical analysis, rock bolts and shotcrete have been recommended (Table 1).

\section{CONCLUSIONS}

The project area extensively covers dolomite and minorly covers slate. The rock mass classification showed fair to good quality of dolomite and poor to fair quality of slate. Geotechnical study showed that the surface wedges would form in intake portal and powerhouse site, In the headrace tunnel structural wedges would be formed due to underground excavation and would be stabilized with the help of shotcrete and rock bolting.

\section{ACKNOWLEDGEMENTS}

We thank Nepal Electricity Authority for providing support to carry out work. We thank S. Shrestha and S. K. Dwivedi for paperworks and field assistance.

\section{REFERENCES}

Bieniawski, A.T., 1974. The point load test in geotechnical practice. Engineering Geology, v. 9, pp. 1-11.

Bieniawski, A.T., 1989. Engineering rockmass classification: a complete manual for engineers and geologist in mining, civil, and petroleum engineering. Wiley Interscience Publication, John Wiley and Sons, USA, 248p.

Grimstad, E. and Barton, N., 1993. Updating the Q-system for NMT. Proceeding Int. Symp. on sprayed concretemodern use of wet mix sprayed concrete for underground support, Fagernes, (Eds. Kompen, Opsahl and Berg). Norwegian Concrete Association, pp. 17 -22.

Hoek, E. Kaiser, P.K. and Bawden, W.F., 1995. Support of underground excavation in hard rock. Oxford and IBH Publishing Co. Pvt. Ltd. New Delhi, 215p. Jnawali, B.M. and Tuladhar, G.B., 1996. Geological Map of parts of Tanahun, Gorkha and Nawalparasi District, Sheet No. 72A/5 (1:50,000) Published by the Department of Mines and Geology, Government of Nepal.

NEA, 2001. Feasibility study of Upper Seti Hydroelectric Project. Unpublished Report, Kthamandu, NEpal, pp. 24. NEA, 2006. Feasibility study of Upper Seti (Damauli) 
Storage Hydroelectric Project. Unpublished Report, Kthamandu, NEpal, pp. 30.

Regmi, N.K, 2003. Geology and geotechnical studies of Upper Seti Hydroelectric Project Damauli, Western Nepal, Unpublished M. Sc. Thesis submitted to the Central Department of Geology Tribhuvan University, Kathmandu, Nepal, 78p.

Rocsciences Inc., 2003. Theory manual for surface and underground wedge stability analysis, SWEDGE 3.0 and UNWEDGE 3.0 (www.rocsciences. com) Shorey, P.R., 1994. A theory for in situ stresses in isotropic and transversely isotropic rock. Int. Jour. Rock Mech. Min. Sci. and Geomech. Abstract, v. 31, no. 1, pp. 23-34.

Serafim, J.L. and Pereira, J.P., 1983. Consideration of the geomechanical classification of Bieniawski. Proc. Int. Symp. on Engineering Geology and Underground Construction, Lisbon, pp. 33-44. 